\title{
Tysk rasepsykologi
}

\begin{abstract}
I 1935 anmeldte Ørnulv Ødegård (1901 -86) en fersk bok i Tidsskriftet - Das Problem des Rassenseele av den tyske gestaltteraputen Bruno Petermann (Tidsskr Nor Lægeforen 1935; 55: 1072-4). Han fant lite av verdi. I anmeldelsen omtales Hans Friedrich Karl Günther (1891-1968). Han var «raseforsker» og en sentral raseideolog i Nazi-Tyskland.
\end{abstract}

Det seiler mange forunderlige eventyrere op i videnskapens kjølvann - det faller alltid noget av, som de kan benytte til eget formål. Antropologien har vært temmelig utsatt, dels fordi den er ung og famlende, dels fordi den arbeider med et materiale som er farlig følelsesbetonet. I dens kjølvann dukket der op den livsanskuelse som gjerne kalles «den nordiske tanke», d. v. s. læren om at den lyse, høivokste, langskallede mennesketype er den ypperste av alle, og derfor bestemt til å herske over de andre raser. Sin første større popularitet fikk den i U. S. A. og Tyskland, hvor den kom vel med som anstand for en våknende imperialisme - England, klok av langvarig verdensherredømme, holdt sig mere tilbake. I Amerika satte den en tid et visst preg på immigrasjonspolitikken, men har efter hvert tapt terreng fordi den måtte støte mektige folkegrupper (irlenderne og italienerne i politikk og jødene i business). I Tyskland har den ulmet siden krigen og blev så av Hitler ophøiet til Statsvidenskap (sit venia verbo). [...]

Det fremgår med all ønskelig tydelighet av hans omfattende studier at der ikke finnes noget som helst brukbart materiale å støtte en rasepsykologi på; men allikevel reiser han ikke engang noget bestemt krav om at et slikt rasjonelt grunnlag først skaffes. Hans konklusjon blir derfor simpelthen Günthers lære, i gjennemsiktig psykologisk-filosofisk omklædning [...]

Boken viser klart hvor ugjørlig det er å levere noget videnskapelig forsvar for den religiøst-politiske lære som kalles «den nordiske tanke»; forf. antyder at den er byg- get på intuisjon mere enn på erfaring, og det stemmer vel på en vis. Den viser også at vi under de nuværende forhold neppe kan vente meget av verdi om dette og beslektede emner fra den tyske litteratur.

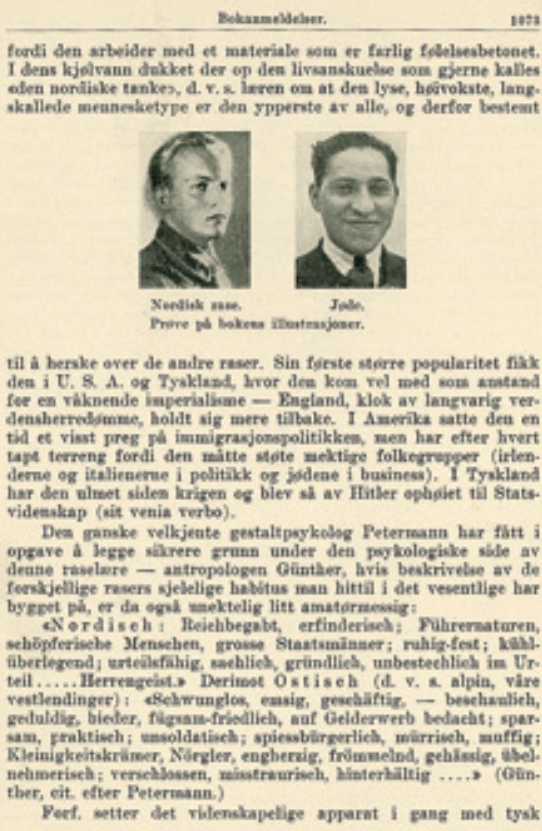

En faksimile fra boken Das Problem des Rassenseele ble brukt i Tidsskriftets anmeldelse i 1935 